\title{
Pluvial flooding in Urban Areas Across the European Continent
}

\author{
Marija Prokić ${ }^{A}, B^{*}$, Stevan Savić ${ }^{C}$, Dragoslav Pavić \\ Received: October 07, 2019 | Revised: December 23, 2019 | Accepted: December 24, 2019 \\ DOI: $10.5937 / g p 23-23508$
}

\begin{abstract}
Pluvial flooding is a result of overland flow and ponding before the runoff enters any watercourse, drainage system or sewer, or cannot enter it because the network is full to capacity, usually caused by intense rainfall. River and coastal floods get the most attention since they are largest and last the longest, while pluvial floods are relatively marginalized in research. Therefore, the main goal of this research was to show risk posed by pluvial floods, their connection to current global climate change processes, present effects of flooding in European cities, as well as what we can expect in the future. Furthermore, the aims were to present and get more familiar with scientific projects, strategies, directives and measures devised both on national and international levels, that deal with urban pluvial flood issues across the European continent. Climate change projections indicate that there will be an increase in the frequency and intensity of rainfall events throughout Europe and along with ongoing urbanization, the problem of pluvial flooding will most certainly require more attention, which it is starting to receive. Some countries have already developed their strategies and initiatives and implemented both structural and non-structural measures, such as spatial planning, constructional measures, information systems, reducing land sealing through policies, building codes and standards, on-site improvement of retention, infiltration, evaporation, and rainfall water recycling with the use of green roofs, permeable or porous pavements, rain gardening or urban rainwater harvesting. At the same time, there are numerous research papers, studies, conferences and workshops devoted to the problem of pluvial flooding and its management carried out in an attempt to properly deal with this hazard.
\end{abstract}

Keywords: urban areas; pluvial flooding; climate change; precipitation; scientific projects; water management; Europe

\section{Introduction}

Floods are the most prevalent natural hazard in Europe. Between 1998 and 2009, Europe suffered over 213 major damaging floods (Bakker et al., 2013). Coastal and river floods receive the most attention as they are generally the floods that are largest and last the longest, while pluvial floods are relatively underrepresented in research (Nicklin et al., 2019), most likely due to the smaller scale of individual events (Dawson et

\footnotetext{
A University of Niš, Faculty of Sciences, Serbia; marijaprokic91@gmail.com

B PhD candidate at University of Novi Sad, Faculty of Sciences, Serbia

c University of Novi Sad, Faculty of Sciences, Climatology and Hydrology Research Centre, Serbia; stevan.savic@dgt.uns.ac.rs; dragoslav.pavic@dgt.uns.ac.rs

* Corresponding author: Marija Prokić, e-mail: marijaprokic91@gmail.com
} 
al., 2008). The absolute record of annual flood loss of all types of floods in Europe was observed in August 2002, when the material damage exceeded $€ 20$ billion, in nominal value (Kundzewicz et al., 2012).

However, there is an increasing problem of massive and intensifying flood damages in areas away from rivers. For example, in Great Britain two flood events in summer 2007 cost nearly $€ 6$ billion (Falkenhagen, 2010). Recent research has suggested that due to the frequent nature of pluvial floods, cumulative direct damage to property caused by those type of floods equals or may even exceed damage from river and coastal floods (Nicklin et al., 2019). Pluvial floods produce less damage but the frequency is higher and the cumulative damage over the years can be just as high as from fluvial flooding events (Acosta-Coll et al., 2018) or even higher (Szewrański et al., 2018a). For instance, of the 11 ooo properties flooded in autumn of 2000 in the $\mathrm{UK}$, $83 \%$ were outside coastal and fluvial floodplains, suggesting that flooding was caused by local pluvial events, sewer flooding or groundwater (Dawson et al., 2008).

Pluvial flooding can be defined as flooding that results from overland flow and ponding before the runoff enters any watercourse, drainage system or sewer, or cannot enter it because the network is full to capacity and is usually caused by intense localized rainfall. This problem is enhanced in cities with insufficient or non-existent sewer systems (Acosta-Coll et al., 2018). Also, Falconer et al. (2009) state that it's important not to confuse 'pluvial flooding' with 'surface water flooding'. According to them, surface water flooding usually refers to combined flooding in urban areas during heavy rainfall. As such, it includes pluvial flooding, sewer flooding, flooding from small open-channels and overland flows from groundwater springs. Pluvial flooding is also different from 'flash flooding', which may also be associated with high-intensity rainfall but usually arises from a watercourse. Further in the text of this paper terms "urban pluvial flooding", "inland pluvial flooding", "pluvial flooding" "intra-urban system flooding", "urban drainage flooding" and "surface water flooding" will be used interchangeably.

Pluvial flooding only occurs when the rainfall rate exceeds the capacity of storm water drains to evacuate the water and the capacity of the ground to absorb water and this is usually associated with short-duration storms (of up to three hours) and with rainfalls that exceed $20-25 \mathrm{~mm}$ per hour; but it can also occur after rainfalls of smaller intensity, approximately $10 \mathrm{~mm}$ per hour, that happen over longer periods, especially if the ground surface is impermeable by being developed, saturated or frozen (Houston et al., 2011).

However, pluvial floods depend not only on the amount and duration of precipitation but also on the hydrological characteristics of the basin, such as runoff magnitude, antecedent moisture condition, drainage area and soil type (Acosta-Coll et al., 2018). In addition, land use change, particularly urbanization, is also changing the proportion of precipitation which becomes runoff and also reduces the delay between precipitation and the runoff reaching a watercourse (Green et al., 2013).

According to $\mathrm{Li}$ (2012) the urban storm water logging problems result from various causes, such as the uneven distribution of precipitation in time and space, inadequate urban water-logging emergency response systems, decreasing green areas and filling of waterbodies because of urbanization and insufficient capacity in the storm water drainage system without proper maintenance and upgrading.

Other reasons for frequent inundation include outdated sewer-stormwater systems, greater areas of impervious urban fabric and larger urban population (Sušnik et al., 2014). Increasing urbanization often results in an expansion of impermeable areas, whereby the higher proportion of sealed soils result in an increased runoff volume and a decreased response time of a catchment, while further risk comes from urban areas expanding into flood risk areas (Swart et al., 2012).

The main goals of this research are twofold: a) first, to show connection between current global climate change processes and urban pluvial flooding, and present effects of flooding in European cities, as well as what we can expect in the future; b) and secondly, to present strategies, directives and measures devised both on national and international levels, as well as scientific projects that deal with urban pluvial flood issues in order to contribute to better mitigation and adaptation actions in European cities. For our analysis we used the scientific literature in the last 10 to 12 years, as well as official documents from international institutions (such as UN, EU) or national governments.

\section{Climate change and pluvial flooding}

The occurance of pluvial or flash floods due to highintensity rainfall events is nothing new. However, it appears that the frequency with which they are happening, their impact on human lives, damage and disruption is increasing, very likely because of the climate change, and unfortunately it's predicted to increase further (Falconer et al., 2009).

As presented by IPCC Fifth Assessment Report (2014) on the world-wide impacts of climate change on rainfall extremes and urban drainage, it was ob- 
(a) DJF seasona C anges in eavy precipitation (\%), 2071-2100 compare to 1971-2000

RCP4.5

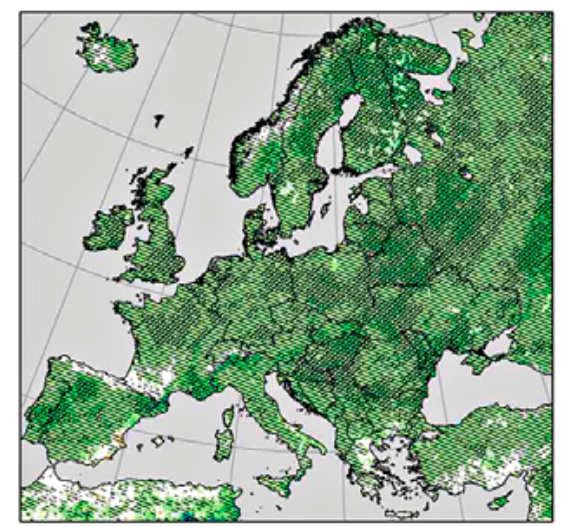

RCP8.5

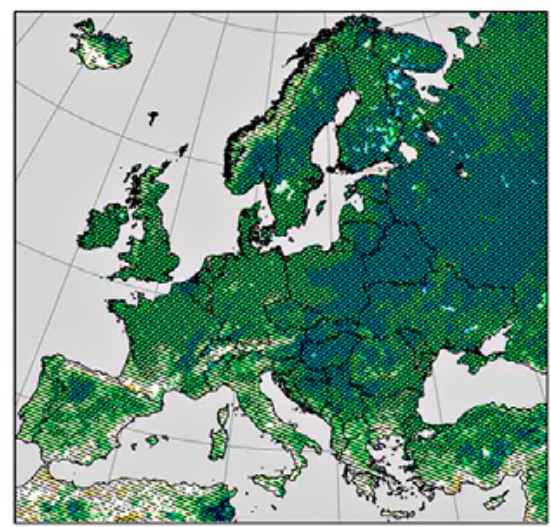

1971-2000

(b) JJA seasonal changes in heavy precipitation (\%), 2071-2100 compared to 1971-2000
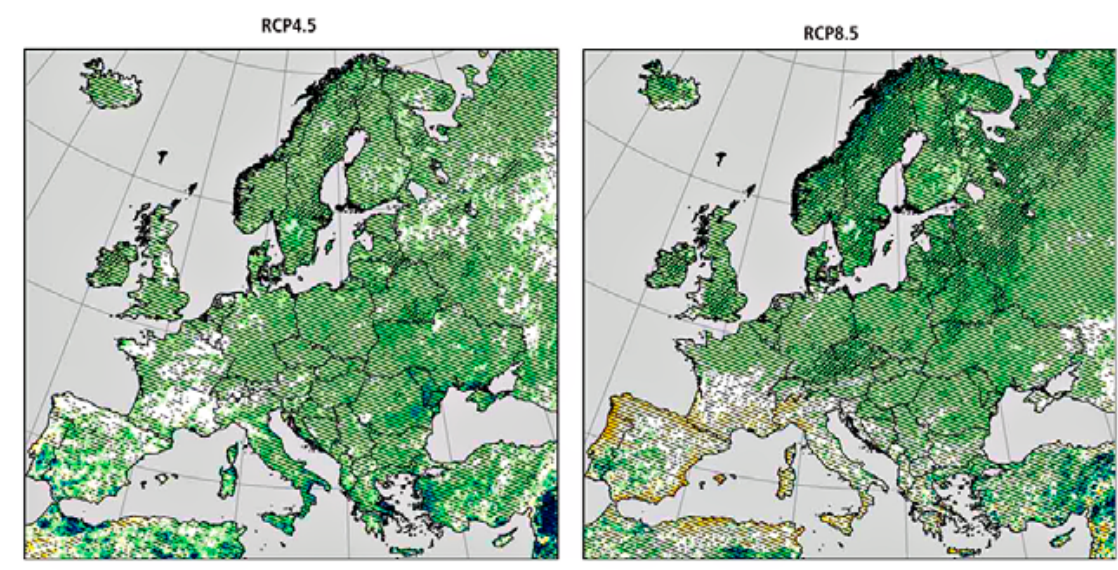

Seasonal changes in heavy

precipitation in percent

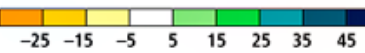

IIIII Significant change

WIII. Robust change

Figure 1. Projected seasonal changes in heavy precipitation for the period 2071-2100 compared to 1971-2000:

a) in the months December to February (DJF) and b) June to August (JJA).

Source: IPCC Fifth Assessment Report, 2014

served that typical increases in rainfall intensity at small urban hydrology scales range from $10 \%$ to $60 \%$ from control periods in the recent past (typically 1961-1990) up to 2100 (Figure 1). These changes in extreme short-duration rainfall events may have significant impacts for urban drainage systems and pluvial flooding. The Danish Meteorological Institute (DMI) predicts that the intensity of the heavy downpours will rise by $20-50 \%$ by 2100 , the most for the very rare events which will have great implication on how the rain will run off surfaces and on the burden on sewer systems and watercourses (Copenhagen Climate Adaptation Plan, 2009).

Climate change is expected to increase the frequency and intensity of rainfall events throughout Europe (Sušnik et al., 2014), especially in the central and northern parts ("STAR-FLOOD"; https://www.starflood.eu/). Flood hazard may also rise during wetter and warmer winters, with increasingly more frequent rain and less frequent snow ("STAR-FLOOD"; https://www.starflood.eu/), while warmer atmosphere will hold higher amount of water vapor (Kundzewicz, 2015).

There will be a marked increase in extremes in Europe, in particular, in heat waves, droughts, and heavy precipitation events, according to the Fifth IPCC Assessment Report (2014). Changes in extreme precipitation depend on the region, with high probability of increased extreme precipitation in Northern Europe (all seasons) and Continental Europe (except summer). This may result in more frequent and more intense floods of various types such as local, sudden floods (flash floods); extensive, longer-lasting pluvial and fluvial floods; coastal floods and snowmelt floods (Menne \& Murray, 2013). With the expected changes, the drainage system built today probably won't be able to meet the desired service levels in the future (Zhou et al., 2012). 
On the other hand, some authors state that climatechange impacts on future extreme precipitation, and consequently on pluvial flooding, is surrounded by large uncertainties. One of the uncertainties lies in the incomplete understanding of processes and components in the Earth's system, resulting in large model uncertainties and thus large variations in projected change of future precipitation extremes between different models (Kaspersen et al., 2017). In addition, climate models provide an assessment of only anthropogenic impacts and usually don't account for natural changes that will occur at the same time, while questions arise about the assumptions behind the climate models and how these assumptions influence the projections (Arnbjerg-Nielsen et al., 2013).

However, the uncertainties associated with climate change should not be an argument for delaying investigating its possible impact on pluvial flooding or postponing adaptation actions. Instead, uncertainties should be accounted for while flexible and sustainable solutions should be sought, some of which will be presented in the following sections.

\section{Current risks from pluvial flooding and future projections}

Risks and adverse effects posed by pluvial flooding are numerous (Figure 2). The direct and indirect impacts of extreme weather include losses in economic terms, the damaging and destruction of private buildings and urban infrastructure, the loss of human lives and the degradation of safety and the deterioration of water quality (Szewrański et al., 2018a). In addition, flooding, especially as a result of intense precipitation, is the predominant cause of weather-related disruption to the transport sector (Pregnolato et al., 2017) and traffic delay and inconvenience (Zhou et al., 2012). Examples of indirect effects are also lost working hours and health impacts on affected residents, which can manifest if sewer water flows onto streets or if pluvial flood water stands stagnant (Sušnik et al., 2014). Furthermore, indirect impacts may occur beyond the location and time of a flood event, such as long-lasting trauma and stress (Szewrański et al., 2018b). On the other hand, average mortality for just drainage floods is low. More than half of the drainage events in the dataset causes one or zero fatalities (Jonkman \& Vrijling, 2008).

According to the European Environment Agency (2012) there are several factors that tend to increase the risk of pluvial flooding:

- Old drainage infrastructure often does not keep pace with an on-going urbanization.

- Combined sewer systems in older areas (rainfall drains into sewers that are carrying sewage and both are transferred to sewage treatment) which are more vulnerable to excessive rainfall than a separate treatment.

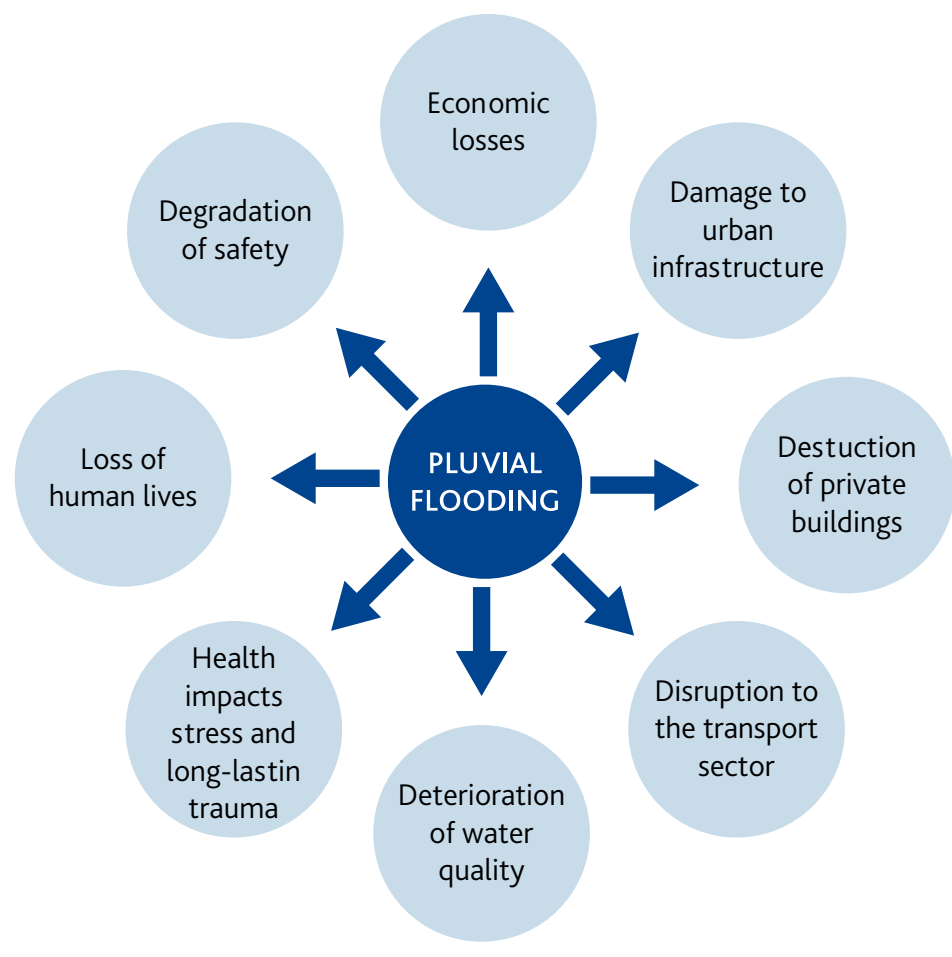

Figure 2. Risks associated with pluvial flooding 
- The existence of inadequate maintenance of the drainage channels to monitor debris and solid waste within such systems.

- Inadequate discharge of excess water to the regional water system.

Douglas et al. (2010) analyzed potential weak points of risk management of serious pluvial flooding in the case study of flooding in Heywood, Greater Manchester in 2004 and 2006. Here it was revealed that all agencies involved in flood risk management, and in particular planners, require more robust, and more localized data. This study has also highlighted that the general public are confused about who does what and who is responsible for pluvial flood risk management, and are not so well informed about how best to protect their properties. Also, many agencies underestimate the ongoing health and social effects of flooding.

Modeling studies show that urbanization and increasing rainfall intensity will increase drainage overflow volumes that will result in more frequent and severe pluvial flooding (Miller \& Hutchins, 2017). At present about $55 \%$ of the global population live in cities and by 2050 almost two thirds of the world's population will live in urban environments (Sörensen et al., 2016). Over $80 \%$ of the population in Britain lives in urban areas while it's predicted that population growth will reach 74.3 million by 2039 (Miller \& Hutchins, 2017).

A new study shows that the total urban area exposed to flooding in Europe has increased by $1000 \%$ over the past 150 years (Jongman, 2018). This means that urbanization with an increase of non-permeable surfaces and lack of natural drainage created additional flooding issues that did not previously exist and that never before there had been so many human assets that were in the way of floods like today. And according to Kazmierczak \& Cavan (2011), the negative correlations between green space cover and the proportion of an area susceptible to flooding suggest that the increasing amount of sealed surfaces in an area aggravates the problem of flooding through increased runoff and reduced infiltration capacity. Furthermore, Guerreiro et al. (2017) developed a map of Europe which represents a percentage of city flooded for historical hourly rainfall for a 10-year return period (Figure 3).

The growing urban population and degree of urbanization puts great pressure on the existing drainage systems, increasing the likelihood of them being overwhelmed ("Urban pluvial flooding and climate change: London (UK), Rafina (Greece) and Coimbra (Portugal)"; https://www.imperial.ac.uk/grantham/ research/resources-and-pollution/water-securityand-flood-risk/urban-flooding/). Systems currently designed for a 20-year return period of flooding,

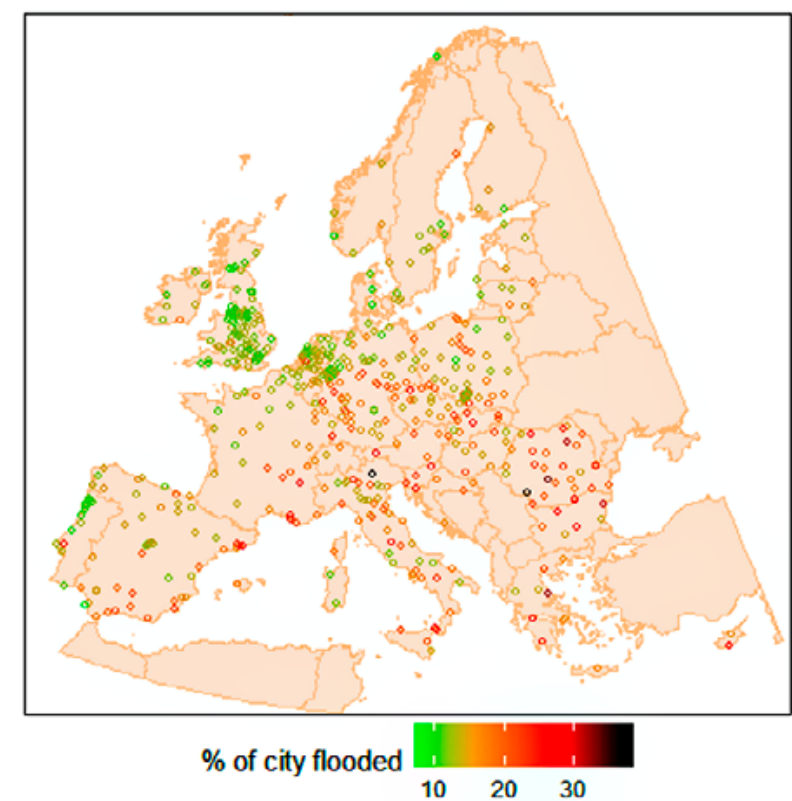

Figure 3. Percentage of city flooded across European continent for historical hourly rainfall for a 10-year return period. Source: Guerreiro et al., 2017

might flood with a mean recurrence interval of 5 years by the end of the century ("Flash floods and Urban flooding"; https://www.climatechangepost.com). On 7 th August in 2002, an inch of rain fell in central London in 30 minutes during the evening "rush hour", resulting in the closure of 5 mainline railway stations, and considerable disruption as London's drainage infrastructure was too old and overloaded to cope with such events (Crichton, 2005). According to the UK statistics ("Facts About Floods in the UK"; https://rainbow-int-franchise.co.uk/flooding-statistics-uk/) the residents of around 2.4 million UK properties are at risk from fluvial and coastal flooding each year, while a further 2.8 million are susceptible to surface wateror pluvial - flooding.

Kaspersen et al. (2017) in their research found that urban development in Odense and Vienna influences the extent of flooding considerably, while only marginally affecting the degree of flooding for Strasbourg and Nice. This suggests that, while further soil sealing in Odense and Vienna (and similar urban areas) should be considered very carefully, as it may substantially increase their exposure to pluvial flooding, urban development effect on pluvial flooding varies locally and should be considered with that in mind.

The financial implications of pluvial flooding can be significant. It is estimated that in the Netherlands, between 1986 and 2009 the total damage from pluvial floods was $€ 674$ million (Sušnik et al., 2014). Nicklin et al. (2019) did the research and used a combination of 3D flood modelling and the WSS (Dutch 'Waterschadeschatter') flood damage estimation tool to assess 
direct flood damage from a $60 \mathrm{~mm} / 1$-h pluvial flood event in two urban areas: Belgrave (Leicester, United Kingdom) and Lombardijen (Rotterdam, the Netherlands). For Belgrave, direct damage was estimated at roughly $€ 11$ million, while for Lombardijen direct damage was $€ 12.4$ million. In England and Wales during summer of 2007 there were about 48 ooo households and nearly 7300 businesses flooded (Menne \& Murray, 2013) while insurance claims from the homes and businesses affected are approaching $£_{3}$ billion and other costs amount to around $£ 1$ billion (Environment Agency, 2007). According to Bernet et al. (2017) in Switzerland, of all damage due to surface water floods and fluvial floods between 1999 and 2013, surface water floods are responsible for at least $45 \%$ of the flood damage to buildings and $23 \%$ of the associated direct tangible losses.

Houston et al. (2011) estimated that almost 2 million people in urban areas in the UK face an annual 0.5 per cent probability (' 1 in 200-year') of pluvial flooding. Most of the areas with lower percentage of city flooded are in the north and west coastal parts of Europe, while the higher percentages are predominately in continental and Mediterranean areas (Guerreiro et al., 2017). When talking about the Mediterranean region, major population and economic growth has taken place along its coast in the past century, which led to extension of urban settlements inside flood prone areas (Gaume et al., 2016). Lugeri et al. (2006) analyzed flood risk exposure in 13 European countries and found that Slovenia has the highest share of urban fabric built in flood prone areas - more than $70 \%$.

An estimated 3.8 million properties are thought to be at risk from pluvial flooding in England which rep- resent around 10\% of all properties, while in Scotland some 15 ooo properties have been estimated to be at pluvial flood risk (Houston et al., 2011). The expected annual damages from urban flooding in the UK are estimated at $£ 0.27$ billion which compares to $£ 0.6$ - 2.1 billion for fluvial and coastal flooding and the estimate for the future is that this could be as much as $£_{2}$ to 15 billion by 2080 compared to $£ 1.5-20$ billion for fluvial and coastal flooding (Dawson et al., 2008). Furthermore, Evans et al. (2008) in the Pitt Review estimated that the future risk from the intra-urban system flooding might rise by the 208 os to be of the same order as fluvial and coastal flood risk.

Menne \& Murray (2013) did the research on the floods in the European region and their health effects and found that in the period between 2005 and 2010, 16 countries were affected by pluvial floods: Bosnia and Herzegovina, Croatia, Czech Republic, Hungary, Malta, Poland, Republic of Moldova, Serbia, Slovenia, Spain, Sweden, Tajikistan, Republic of North Macedonia, Turkey, Ukraine, United Kingdom (England and Wales). And as mentioned in the previous part, with the projection for the continuous increase of heavy rain contribution to total precipitation (Santato et al., 2013) and with current urbanization and population growth, it is estimated that by 2050, 3.2 million people in urban areas in the UK could be at risk from pluvial flooding, which is an increase of 1.2 million (Houston et al., 2011).

Figure 4, developed by European Environment Agency (2012), shows the projected change in the annual number of days with heavy rainfall in 2071-2100 against the reference period (1961-1990). Projections for regions south of the Alps show a decline in the number of days with extreme precipitation of up to

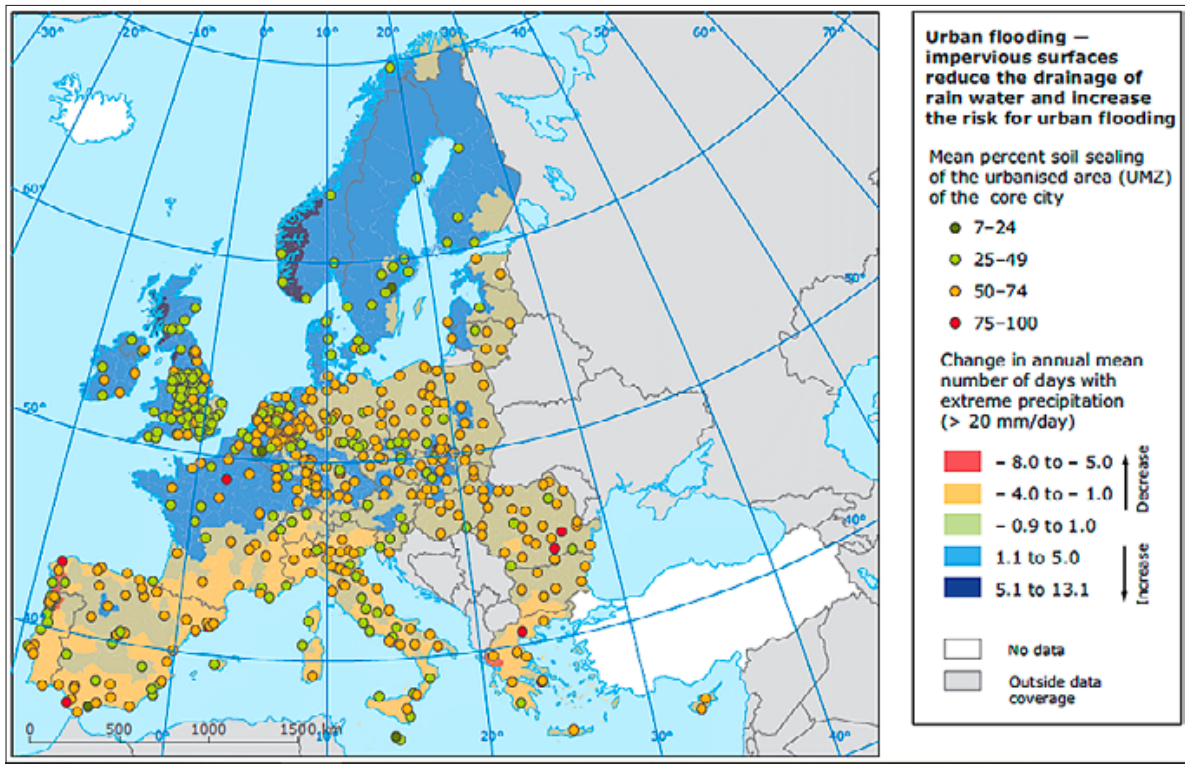

Figure 4. Urban flooding - impervious surfaces reduce the drainage of rain water and increase the risk for urban flooding.

Source: European Environment Agency, 2012 
five days and more. Most regions north of the Alps expect an increase, mostly of one to three days. In addition, this map shows the degree of mean soil sealing per urbanized areas of cities. Cities with high soil sealing and an increasing number of intensive rainfall events - in particular in north-western and northern Europe - face a higher risk of urban drainage flooding. Nevertheless, cities in areas with a decreasing number of such events but high soil sealing still face a flooding risk, just less often. Cities of high and low soil sealing can be found in all regions and do not cluster in a particular region with the exception of low sealing levels in cities in Finland, Norway, Slovenia and Sweden. Cyprus, Estonia, Greece and Luxembourg are countries with a high share of cities with elevated levels of soil sealing.

\section{Examples of pluvial flooding events across European continent}

Gaume et al. (2009) have compiled a comprehensive data record of flash floods for seven European hydrometeorological regions. This inventory was the first step towards an atlas of extreme flash floods in Europe while the objective was to document a minimum number of 30 floods in each region, especially the events considered as the most extreme or "top 30 " flash floods which are homogeneously distributed over the selected period. However, this research didn't include pluvial floods and there couldn't be found any similar analysis that would focus on pluvial flooding events in Europe. Therefore, this section will provide a few examples of pluvial flooding occurrences that had significant economic and social impact on the communities in Europe affected by this hazard.

In the summer of 2007, floods that struck much of the United Kingdom during June and July affected hundreds of thousands of people. This event was the most serious inland pluvial and fluvial flood ever recorded, with 13 deaths, about 7000 people rescued from floodwaters by the emergency services, and about 48 ooo households and nearly 7300 businesses flooded (Menne \& Murray, 2013), while the insurance claims from the homes and businesses flooded approached $\mathfrak{k}_{3}$ billion (Environment Agency, 2007). The floods caused the loss of essential services, almost half a million people were without water or electricity supply, transport

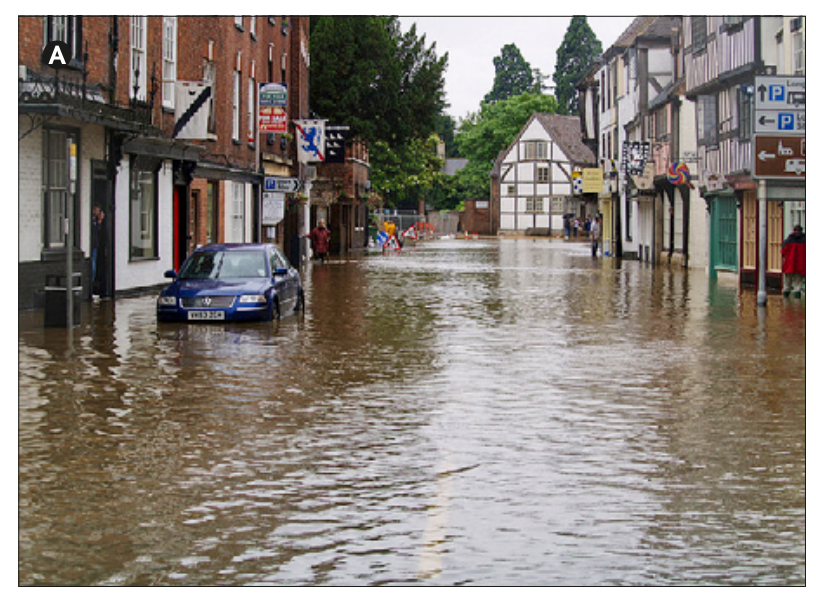

networks failed, a dam breach was narrowly averted, and emergency facilities and telecommunications were put out of action (Menne \& Murray, 2013).

During June, July, and August of 2007 a succession of depressions tracked over the UK, bringing heavy rainfall and triggering multiple flooding events (Stuart-Menteth, 2007). With $414 \mathrm{~mm}$ of rain, England and Wales haven't seen a wetter May to July since records began in 1766 (Environment Agency, 2007). On 12th June 2007, a total of $98.3 \mathrm{~mm}$ of rain fell in one hour in East and South Belfast which resulted in both fluvial flash flooding and pluvial flooding which caused major disruption throughout Belfast with over 400 properties affected (Falconer, 2009). Two particularly large floods hit within just four weeks of each other. First, the northeast of England was badly affected following heavy rainfall on June 25 th, which caused flooding in cities and towns such as Sheffield, Doncaster, Rotherham, Louth, and Kingston-upon-Hull (Figure 5). Some areas were hit again by further flooding after more severe rains on July 2oth, which affected a much larger area of central England, including Oxford, Gloucester, Tewkesbury, Evesham, and Abingdon (Stuart-Menteth, 2007). According to the emergency services, that summer saw the greatest number of search and rescue missions in the country since the Second World War (Environment Agency, 2007).

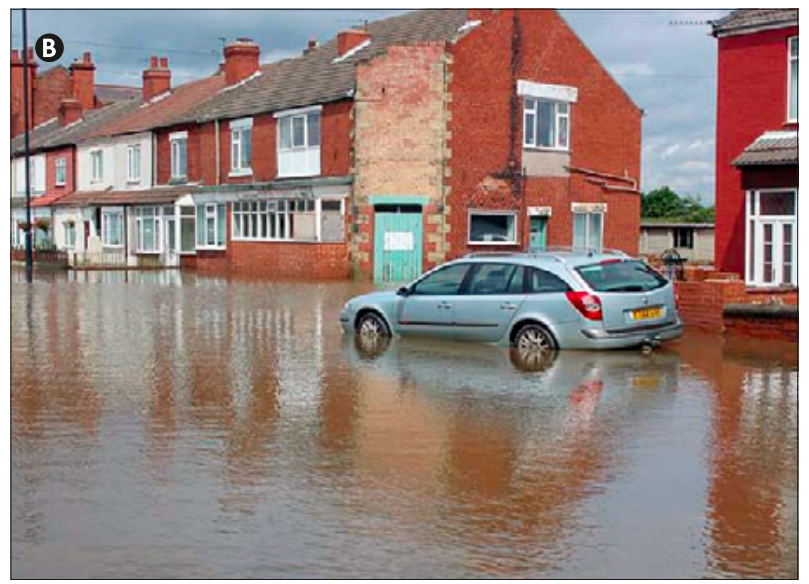

Figure 5. Pluvial floods in the UK in summer 2007: A) Tewkesbury, England; B) Toll Bar, Yorkshire, England. Source: Stuart-Menteth, 2007 
Just a couple of years before this event, at the end of July in 2002, another extreme case of storms affected much of the UK, especially West and central Scotland, and produced extreme amount of rainfall at several locations in localized intense heavy downpours generating surface water flooding and pluvial flooding affecting small urban watercourses, drainage systems and sewers (Falconer, 2009). The full storm began at approximately 10:30 am on 30 July 2002 and continued for a total of approximately 10 hours, it measured $75 \mathrm{~mm}$ depth and had a maximum intensity of $94.5 \mathrm{~mm} / \mathrm{h}$ which can be linked to a maximum return period of 100 years (Wilson \& Spiers, 2003).

According to the European Environment Agency (2012), on July $2^{\text {nd }}$ 2011, Copenhagen in Denmark was hit by a huge thunderstorm after a substantially hot period. During a two hour period over, $150 \mathrm{~mm}$ of rain fell in the city centre. This became the biggest single rainfall in Copenhagen since measurements began in the mid-18oos. The city's sewers were unable to handle all of the water and as a result many streets were flooded and sewers overflowed into houses, basements and onto streets thereby flooding the city (Figure 6). Insurance damages alone were estimated at $€ 650-700$ million. Damage to municipal infrastructure not covered by insurance, such as roads, amounted to $€ 65$ million.

The Marmara region in north-western Turkey suffered from a series of floods during the period from $7^{\text {th }}$ until $10^{\text {th }}$ September in 2009, with 35 ooo people affected, 32 human losses and more than $\$ 100$ million of economic damage. The 24-hour rainfall amounts varied between 100 and $253 \mathrm{~mm}$ during the flooding period and additional factors such as land use changes, urbanization, poor drainage, and construction and settling in the flood-prone areas worsened consequences of the floods, especially in major urban areas of the region. Istanbul suffered most from floods where some suburban districts were submerged and the city's highways were turned into rivers and transportation and communication infrastructures were damaged (Kömüşcü \& Çelik, 2012).

On the $18^{\text {th }}$ September in 2007 an extreme rainfall event affected approximately one-third of Slovenia, causing the damage of $€ 200$ million and six casualties (Rusjan et al., 2009). In the town Železniki, the observed maximum daily amount of rainfall was nearly $200 \mathrm{~mm}$, which was the highest recorded amount of precipitation since the beginning of the measurements in 1930 and it devastated the town of Železniki: three people lost their lives, while it was estimated that the flood caused nearly €10o million of damage (Markošek, 2008). In June of 2010 storms hit the south-east of France and the large amounts of heavy rain led to localized flash flooding and pluvial flooding which caused severe damage and loss of life in southern France, and a number of towns in the department of Var were affected, with hundreds of homes flooded (Moreau \& Roumagnac, 2010). Torrential rainfall hit southern Italy and produced major flooding in parts of Sicily and Calabria on October $4^{\text {th }}$ 2018. The urban area of Catania, Sicily was strongly hit where streets turned into rivers (Figure 7). Catania experienced intense rainfall with about $50 \mathrm{~mm}$ falling in only 20 minutes as the severe thunderstorm passed ("Major flash floods hit urban areas of Catania, Sicily"; http://www.severe-weather.eu/news/major-flash-floods-hit-urban-areas-of-catania-sicily/). In May and June of 2016, Germany was struck with recurring thunderstorms, with damage across Germany totaled $€ 2.6$ billion (Faust, 2018). Parts of Germany have come to a standstill after storms and torrential rain, especially in the south in May this year as well. One person died and daily life has been disrupted. Heavy rain and thunderstorms, mainly in southern and central Germany, have left rivers overflowing and streets flooded (Silk, 2019).
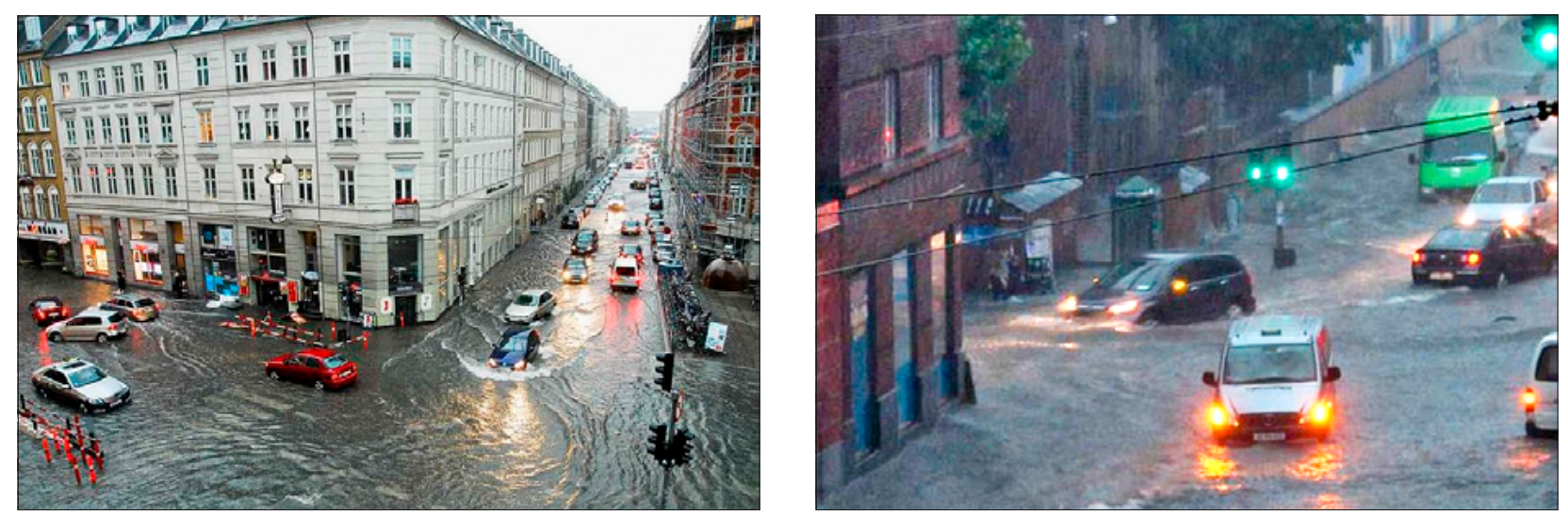

Figure 6. Pluvial flood in Copenhagen, Denmark on $2^{\text {nd }}$ July, 2011

Source: $h$ ttps://oppla.eu/casestudy/18017 and https://www.eea.europa.eu/articles/turning-the-urban-challenge-into 

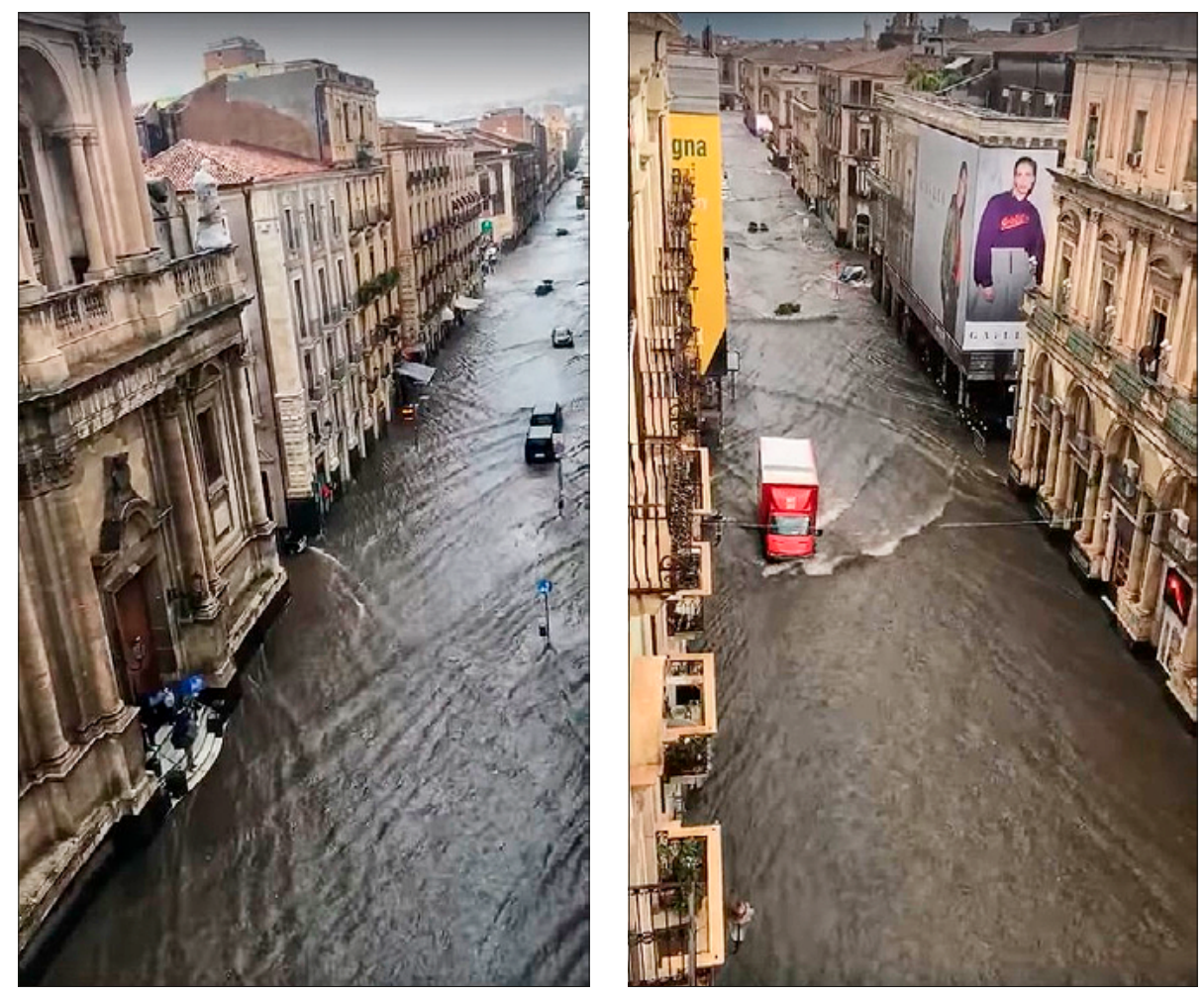

Figure 7. Pluvial flood in Catania, Sicily on $4^{\text {th }}$ October, 2018

Source: Internet 10

\section{Pluvial flooding risk management}

\section{Adopted measures and strategies}

Measures and strategies that increase the specific response capacity of cities to flooding, according to Swart et al. (2012), can be classified into structural and non-structural measures or into grey, green and soft measures (Figure 8). The response capacity measures include spatial planning, constructional measures, risk acceptance, behavioral adaptation, information systems, technical flood protection and increasing natural water retention in catchment areas and reducing land sealing. Structural measures decrease the risk and they are mostly effective, but they usually involve management problems. On the other hand, nonstructural measures reduce vulnerability and when they are permanent they are reliable but can be socially costly while when they are temporary and less costly they become less reliable (Working Group F, 2010). These can be classified as passive and active where active non-structural measures are those that promote direct interaction with people, such as training, local management, early warning systems for people, public information, while passive measures involve policies, building codes and standards, and land use regulations (Acosta-Coll et al., 2018). Some of the adaptation measures involve the on-site improvement of retention, infiltration, evaporation, and rainfall water recycling with the use of green roofs, permeable or porous pavements, rain gardening, urban rainwater harvesting, or the application of water-absorbing geocomposites (Szewrański et al., 2018b).

The problem of pluvial flooding is slowly starting to receive more attention, according to the interviews conducted by Mees et al. (2016) and numerous research papers (Candela \& Aronica, 2016; Falconer et al., 2009; Szewrański et al., 2018a/b; Fritsch et al., 2016), conferences and workshops (Third Hydrology Forum, Oslo, 2016; Flash Floods and Pluvial Flooding Workshop, Calgari, 2010; 3rd European Conference on Flood Risk Management, Lyon, 2016) done on this topic. Through further examples of different projects, strategies and initiatives implemented in European countries separately or in mutual cooperation across the continent, various methods of urban pluvial flooding management will be observed.

For instance, The EU Directive on the assessment and management of flood risks (pluvial floods included), often referred to as the Floods Directive, entered into force on $26^{\text {th }}$ November 2007 , which main aim is to reduce and manage the risks posed by floods to human health, the environment, cultural heritage and economic activity (Bakker et al., 2013). Floods Directive contains a three-stage approach: first, a preliminary flood risk assessment must be undertaken, then flood hazard maps and flood risk maps are to be pre- 


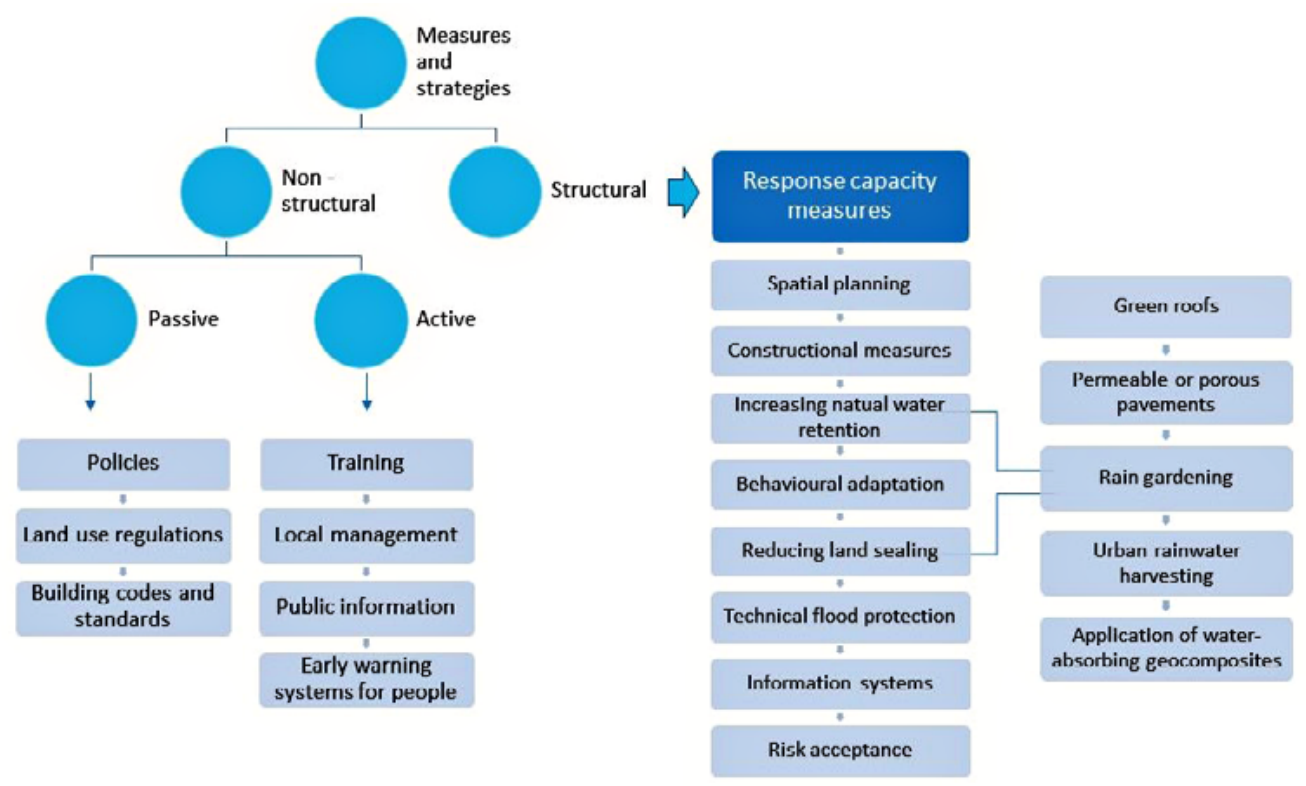

Figure 8. Measures and strategies developed for pluvial floods management

pared and in the final stage, member states must establish Flood Risk Management plans. Priest et al. (2016) did an analysis which indicates that the effect of the Flood Directive is highly variable among the six European countries they studied (Belgium, England, France, the Netherlands, Poland, and Sweden), but despite the shortcomings of the Flood Directive in directly affecting flood risk outcomes, it has had a positive influence in stimulating discussion and flood risk management planning in member states that were perhaps lagging behind. Or, another example, according to Land Use Consultants (2003) Sustainable Urban Drainage Systems, involves moving away from conventional piped systems and toward engineering solutions that mimic natural drainage processes and minimize adverse effects on the environment which may take the form of infiltration systems whereby water is soaked away into the ground or they may be attenuation systems, which release flows gradually to watercourses or sewers. Separate storm water and foul water systems can increase drainage capacity and reduce the likelihood of sewage mixing with pluvial flood water (Houston et al., 2011).

As mentioned previously, there are different uncertainties that surround risk assessments for urban flooding, particularly connected to the climate change models and small-scale projections of extreme precipitation. Kaspersen \& Kirsten (2017) proposed a way to address these uncertainties by using a very detailed integrated data and modelling approach, such as the DIAS Danish Integrated Assessment System tool they described in detail, which can help identify particularly vulnerable and valuable assets that climate change adaptation measures should protect.
While the warning about extreme weather events in Germany is done nationwide by the German Meteorological Service, flood forecasting and warning is decentralized in Germany which poses the main challenge of handling of measured data coming from various providers and monitoring networks in individual formats (Osnabrugge et al., n.d.). German Water Association (DWA) set up different working groups with the aim to establish technical standards and provide affected interest groups with guidelines and practical advice which in the year 2013 during a heavy rainfall event with a return period of about 100 years has proven to significantly reduce flood risk and gain acceptance in public (Fritsch et al., 2016). As a further example, Hamburg has introduced a separate rain water drainage system in recent years and introduced financial penalties, if rain water is not locally drained by home owners (Schlünzen \& Bohnenstengel, 2016).

\section{Projects related with pluvial flooding issues}

The following table represents various examples of different projects, strategies and initiatives implemented in European countries separately or in mutual cooperation across the continent that deal with and manage pluvial flooding.

Good examples of pluvial flooding risk management could be found outside of Europe as well and perhaps studied further in the attempt to adapt good practices from across the world. For example, China is currently in the process of implementing a policy initiative called sponge cities to holistically tackle urban pluvial flooding while promoting sustainable urban development with reduced environmental impact. This initiative is well-grounded in scientific under- 
standing of urban hydrology and sustainable stormwater management. It seeks to mitigate rising flood disasters and related water and environmental issues by green infrastructure and low impact technologies integrated with urban development through planning and design (Jiang et al., 2018).

Table 1. Summary of the projects related with pluvial flooding in urban areas across the European continent

\begin{tabular}{|c|c|c|c|c|c|}
\hline № & Project title & Objective & Realization & Country(ies) & webpage \\
\hline 1 & $\begin{array}{l}\text { Floods Directive } \\
\text { (Directive } \\
\text { 2007/60/EC) }\end{array}$ & $\begin{array}{l}\text { Reducing and managing the risks posed by floods to } \\
\text { human health, the environment, cultural heritage and } \\
\text { economic activity. }\end{array}$ & $\begin{array}{l}2007- \\
\text { present }\end{array}$ & EU & $\begin{array}{l}\text { https://ec.europa.eu/ } \\
\text { environment/water/ } \\
\text { flood_risk/ }\end{array}$ \\
\hline 2 & $\begin{array}{l}\text { FloodProBe (Flood } \\
\text { Protection of the } \\
\text { Built Environment) }\end{array}$ & $\begin{array}{l}\text { Providing cost-effective solutions for flood risk } \\
\text { reduction in urban areas and developing technologies, } \\
\text { methods and tools for flood risk assessment and for } \\
\text { the practical adaptation of new and existing buildings, } \\
\text { critical infrastructure and flood defences leading to a } \\
\text { better understanding of vulnerability, flood resilience } \\
\text { and defence performance ("Civil Engineering \& } \\
\text { Environmental Hydraulics"). }\end{array}$ & $\begin{array}{l}2009- \\
2013\end{array}$ & $\begin{array}{l}\text { The } \\
\text { Netherlands, } \\
\text { UK, France, } \\
\text { Norway, } \\
\text { Poland, Spain. }\end{array}$ & $\begin{array}{l}\text { http://www. } \\
\text { floodprobe.eu }\end{array}$ \\
\hline 3 & $\begin{array}{l}\text { STAR-FLOOD } \\
\text { (Strengthening } \\
\text { And Redesigning } \\
\text { European Flood risk } \\
\text { practices: Towards } \\
\text { appropriate and } \\
\text { resilient flood } \\
\text { risk governance } \\
\text { arrangements) }\end{array}$ & $\begin{array}{l}\text { Analysing, explaining, evaluating and designing policies } \\
\text { to better deal with flood risks from rivers in urban } \\
\text { agglomerations across Europe. }\end{array}$ & $2012-2016$ & $\begin{array}{l}\text { The } \\
\text { Netherlands, } \\
\text { UK, Belgium, } \\
\text { Sweden, } \\
\text { Poland, } \\
\text { France. }\end{array}$ & $\begin{array}{l}\text { https://www. } \\
\text { starflood.eu }\end{array}$ \\
\hline 4 & Eye on Earth & $\begin{array}{l}\text { Online mapping tool which shows the mean percentage } \\
\text { of each city covered with impervious surfaces such as } \\
\text { buildings, concrete or asphalt, where the soil is 'sealed'. }\end{array}$ & $2011-2016$ & Global & $\begin{array}{l}\text { https://eye-on-earth. } \\
\text { net/ }\end{array}$ \\
\hline 5 & $\begin{array}{l}\text { IMPREX (Improving } \\
\text { edictions and } \\
\text { Management } \\
\text { of Hydrological } \\
\text { Extremes) }\end{array}$ & $\begin{array}{l}\text { This project was designed to support the reduction of } \\
\text { Europe's vulnerability to hydrological extremes through } \\
\text { improved understanding of the intensity and frequency } \\
\text { of future disrupting events and is built upon a strong } \\
\text { team of experts from public and private sectors } \\
\text { as well as universities and research institutes with } \\
\text { complementary skills and experiences (Osnabrugge et } \\
\text { al., n.d.). }\end{array}$ & $2015-2019$ & EU & $\begin{array}{l}\text { https://www.imprex. } \\
\text { eu/ }\end{array}$ \\
\hline 6 & FloodCitiSense & $\begin{array}{l}\text { Integrating crowdsourced hydrological data, } \\
\text { collaboratively monitored by local stakeholders, } \\
\text { including citizens, making use of low-cost } \\
\text { sensors and web-based technologies, into a } \\
\text { flood early warning system. }\end{array}$ & $2017-2020$ & $\begin{array}{l}\text { Belgium, the } \\
\text { Netherlands, } \\
\text { UK }\end{array}$ & $\begin{array}{l}\text { http://floodcitisense. } \\
\text { webflow.io/ }\end{array}$ \\
\hline 7 & $\begin{array}{l}\text { FRC } \\
\text { (FloodResilienCity) }\end{array}$ & $\begin{array}{l}\text { Integrating the increasing demand for more houses and } \\
\text { other buildings in urban areas with the increasing need } \\
\text { for more and better flood risk management measures } \\
\text { (Ashley et al., 2019). }\end{array}$ & $2007-2013$ & $\begin{array}{l}\text { France, } \\
\text { Germany, } \\
\text { Ireland } \\
\text { Belgium, } \\
\text { England, the } \\
\text { Netherlands }\end{array}$ & l \\
\hline 8 & FloodList & $\begin{array}{l}\text { European system for Earth monitoring which reports on } \\
\text { all the major flood events from around the world and } \\
\text { raises awareness of the risks of flooding. }\end{array}$ & $\begin{array}{l}2008- \\
\text { present }\end{array}$ & EU & http://floodlist.com \\
\hline 9 & RainGain & $\begin{array}{l}\text { European project aimed at improving the prediction } \\
\text { of pluvial floods in cities where four different types of } \\
\text { radar techniques was tested in four pilot cities: Leuven, } \\
\text { London, Paris and Rotterdam. }\end{array}$ & $2011-2016$ & $\begin{array}{l}\text { Belgium, the } \\
\text { Netherlands, } \\
\text { France, UK }\end{array}$ & $\begin{array}{l}\text { http://www.raingain. } \\
\text { eu }\end{array}$ \\
\hline
\end{tabular}




\begin{tabular}{|c|c|c|c|c|c|}
\hline № & Project title & Objective & Realization & Country(ies) & webpage \\
\hline 10 & URBAN-PREX & $\begin{array}{l}\text { Project for monitoring, forecasting and development } \\
\text { of online public early warning system for extreme } \\
\text { precipitations and pluvial floods in urban areas in the } \\
\text { Hungarian-Serbian cross-border region. Measured } \\
\text { data from the two precipitation networks deployed } \\
\text { in Novi Sad (Serbia) and Szeged (Hungary) (Figure 9) } \\
\text { will be used to fine-tune the remotely sensed data } \\
\text { thus enabling the development of more precise 2-day } \\
\text { forecast model for the Programme area. Measured and } \\
\text { forecasted data are freely available for everyone in } \\
\text { real-time on the project website, project social pages } \\
\text { and mobile android application giving an early warning } \\
\text { to the citizens and public authorities in order to protect } \\
\text { them and prepare their effective response to these } \\
\text { extreme precipitations and pluvial flood situations. }\end{array}$ & $2017-2019$ & $\begin{array}{l}\text { Serbia, } \\
\text { Hungary }\end{array}$ & $\begin{array}{l}\text { http://www.urban- } \\
\text { prex.org/ }\end{array}$ \\
\hline 11 & $\begin{array}{l}\text { Amsterdam } \\
\text { Rainproof }\end{array}$ & $\begin{array}{l}\text { Making Amsterdam resistant to the increasingly } \\
\text { frequent showers and make better use of the free } \\
\text { rainwater that is being drained through water- } \\
\text { permeable paving, green roofs and façade gardens. }\end{array}$ & $2014-2050$ & $\begin{array}{l}\text { The } \\
\text { Netherlands }\end{array}$ & $\begin{array}{l}\text { https://www. } \\
\text { rainproof.nl/ }\end{array}$ \\
\hline 12 & $\begin{array}{l}\text { PLUIE Flood } \\
\text { Prevention Plan } \\
\text { (OECD -The } \\
\text { Organisation } \\
\text { for Economic } \\
\text { Co-operation and } \\
\text { Development) }\end{array}$ & $\begin{array}{l}\text { Adopting measures that can help to ensure that the } \\
\text { built environment is better adapted to increased } \\
\text { precipitation, such as compulsory installation of } \\
\text { rainwater tanks for new housing promoted through } \\
\text { regional grants for existing housing and to increase } \\
\text { infiltration and evapotranspiration (limit on built-up } \\
\text { areas, choice of permeable materials, plantings and } \\
\text { green roofs). }\end{array}$ & 2008 & Belgium & https://www.oecd.org \\
\hline 13 & $\begin{array}{l}\text { SWITCH } \\
\text { (Sustainable Water } \\
\text { Management } \\
\text { Improves } \\
\text { Tomorrow's Cities' } \\
\text { Health) }\end{array}$ & $\begin{array}{l}\text { Providing systemic solutions for cities and urban areas } \\
\text { in the face of dynamic global urbanisation and climate } \\
\text { change using ecohydrology approaches (Li, 2012). }\end{array}$ & $2006-2011$ & $\begin{array}{l}\text { UK, Poland, } \\
\text { Germany, } \\
\text { Spain, Ghana, } \\
\text { Egypt, } \\
\text { China, Brazil, } \\
\text { Colombia, } \\
\text { Peru, Israel. }\end{array}$ & $\begin{array}{l}\text { http://www. } \\
\text { switchurbanwater.eu/ }\end{array}$ \\
\hline 14 & $\begin{array}{l}\text { Making Space for } \\
\text { Water, Urban Flood } \\
\text { Risk and Integrated } \\
\text { Drainage }\end{array}$ & $\begin{array}{l}\text { This project was aimed to use pilot studies to identify } \\
\text { effective ways for partnerships to manage surface } \\
\text { water flooding in high risk urban areas through an } \\
\text { integrated drainage approach. An initial scoping review } \\
\text { was carried out to review ongoing best practice and to } \\
\text { identify current projects that are relevant to the pilots } \\
\text { or should be considered in developing future guidance. } \\
\text { Trial partnerships took place through different lead } \\
\text { organisations and a lessons learnt report has been } \\
\text { produced for each pilot. Based on these reports and the } \\
\text { results of the pilots, a final guidance document will be } \\
\text { produced to highlight recommendations for achieving } \\
\text { successful management. }\end{array}$ & $2007-2008$ & England & $\begin{array}{l}\text { https://webarchive. } \\
\text { nationalarchives.gov. } \\
\text { uk/20090731150607/ } \\
\text { http://www.defra. } \\
\text { gov.uk/environ/fcd/ } \\
\text { policy/strategy/ha2. } \\
\text { htm }\end{array}$ \\
\hline 15 & $\begin{array}{l}\text { Find out if you're at } \\
\text { risk of flooding }\end{array}$ & $\begin{array}{l}\text { Environment Agency flood maps were finally updated } \\
\text { to include details of pluvial flooding, in a bid to provide } \\
\text { a more detailed assessment of overall flood risk. }\end{array}$ & $\begin{array}{l}2013- \\
\text { present }\end{array}$ & UK & $\begin{array}{l}\text { https://www.gov.uk/ } \\
\text { check-flood-risk }\end{array}$ \\
\hline 16 & $\begin{array}{l}\text { Flood wardens } \\
\text { initiative }\end{array}$ & $\begin{array}{l}\text { Under these programmes, interested citizens are } \\
\text { registered and trained to assist in the execution and } \\
\text { coordination of response activities during emergency } \\
\text { events (Mees et al., 2016). }\end{array}$ & I & England & $\begin{array}{l}\text { https://www.dover. } \\
\text { gov.uk/Environment/ } \\
\text { Flooding/Flood- } \\
\text { Wardens.aspx }\end{array}$ \\
\hline 17 & $\begin{array}{l}\text { Management of } \\
\text { risks from natural } \\
\text { hazards }\end{array}$ & $\begin{array}{l}\text { This strategy considers current boundary conditions } \\
\text { such as higher incidence of extreme weather events } \\
\text { including floods and increasing utilisation of our living } \\
\text { environment. }\end{array}$ & 2018 & Switzerland & http://www.planat.ch \\
\hline
\end{tabular}



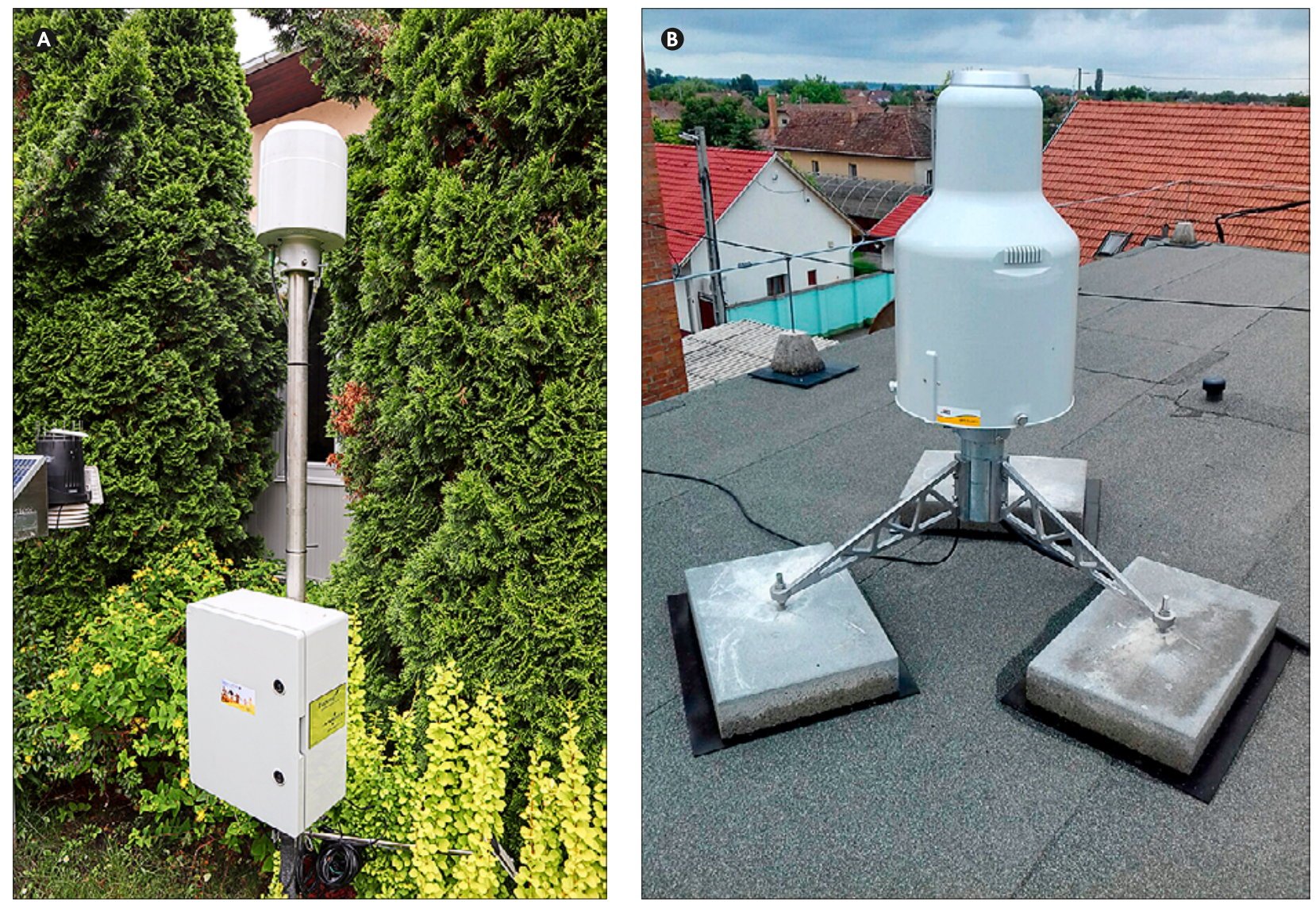

Figure 9. Precipitation sensor types in Novi Sad and Szeged monitoring network, a) Lambrecht rain[e] station in Novi Sad, and b) OTT Pluvio 2 station in Szeged

\section{Conclusions}

Pluvial flooding, or flooding that is a result of intense localized rainfall that exceeds the capacity of a drainage system, is getting wider awareness in Europe. The estimates that cumulative damage from pluvial flooding over the years can be just as high as from fluvial flooding events or even higher is worrying and a cause for a concern. Risks posed by pluvial flooding are numerous, from economic losses, destruction of private buildings and urban infrastructure to the loss of human lives, decrease of water and health impacts.

With climate change projections that there will be an increase in the frequency and intensity of rainfall events throughout Europe and with ongoing urbanization with its own effects, adaptive and sustainable solutions should be explored and pursued as soon as possible.

The problem of pluvial flooding is most certainly starting to receive more attention and some countries have already developed their strategies for deal- ing with this hazard. As this review shows, there are already numerous researches, papers, studies, conferences and workshops dedicated to the problem of pluvial flooding and its management. Various project strategies and initiatives that deal with pluvial flooding risk management have been implemented in some of the European countries separately or in cooperation with one another.

Some of the measures presented include spatial planning, constructional measures, risk acceptance, information systems, early warning systems for people, reducing land sealing through policies, building codes and standards and land use regulations, as well as adaptation measures such as the on-site improvement of retention, infiltration, evaporation, and rainfall water recycling with the use of green roofs, permeable or porous pavements, rain gardening or urban rainwater harvesting.

\section{Acknowledgements}

This research is supported by Interreg-IPA CBC Hungary-Serbia program through the project URBAN-PREX (ID: HUSRB/1602/11/0097). 


\section{References}

Acosta-Coll, M., Merelo, F., Peiro, M.M., \& De la Hoz, E. (2018). Real-Time Early Warning System Design for Pluvial Flash Floods-A Review. Sensors, 18, 2255. DOI:10.339o/s18072255

Arnbjerg-Nielsen, K., Willems, P., Olsson, J., Beecham, S., Pathirana, A., Gregersen, I., Madsen, H., \& Nguyen, V.-T.V. (2013). Impacts of Climate Change on Rainfall Extremes and Urban Drainage Systems. Water science and technology, 68(1), 16-28. DOI:10.2166/wst.2013.251

Ashley, R., Blanksby, J., Maguire, T. \& Leahy, T. (2019). Frameworks for Adapting to Flood Risk: Experiences from the EU's Flood Resilient City Project.

Bakker, M.H.N., Green, C., Driessen, P., Hegger, D., Delvaux, B., van Rijswick, M., Suykens, C., Beyers, J.C, Deketelaere, K., van Doorn-Hoekveld, W., \& Dieperink, C. (2013). Flood Risk Management in Europe: European flood regulation. STAR-FLOOD Consortium, Utrecht, The Netherlands. ISBN: 97894-91933-04-2

Bernet, D.B., Prasuhn, V., \& Weingartner, R. (2017). Surface water floods in Switzerland: what insurance claim records tell us about the damage in space and time. Natural Hazards and Earth System Sciences, 17, 1659-1682. https://doi.org/10.5194/ nhess-17-1659-2017

Candela, A., \& Aronica, G.T. (2016, September). Derivation of Rainfall Thresholds for Pluvial Flood Risk Warning in Urbanised Areas. XXXV Convegno Nazionale di Idraulica e Costruzioni Idrauliche, $14^{\text {th }}-16^{\text {th }}$ September 2016 , Bologna, Italy. https:// doi.org/10.1051/e3sconf/20160718016

Crichton, D. (2005). Flood risk \& insurance in England \& Wales: are there lessons to be learned from Scotland? Technical Papers 1 Benfield Greig Hazard Research Centre

Dawson, R.J., Speight, L., Hall, J.W., Djordjevic, S., Savić, D., \& Leandro, J. (2008). Attribution of flood risk in urban areas. Journal of Hydroinformatics, Vol. 10, No. 4, 275-288. DOI: 10.2166/hydro.2008.054

Douglas, I., Garvin, S., Lawson, N., Richards, J., Tippett, J., \& White, I. (2010). Urban pluvial flooding: a qualitative case study of cause, effect and nonstructural mitigation. Journal of Flood Risk Management, 3, 112-125. DOI:10.1111/j.1753-318X.2010.01061.X

Environment Agency (2007). Review of 2007 summer floods. Environment Agency, Bristol.

European Environment Agency (2012). Urban adaptation to climate change in Europe. Challenges and opportunities for cities together with supportive national and European policies. EEA Report No 2/2012. Copenhagen, Denmark.
Evans, E.P., Simm, J.D., Thorne, C.R., Arnell, N.W., Ashley, R.M., Hess, T.M., Lane, S.N., Morris, J., Nicholls, R.J., Penning-Rowsell, E.C., Reynard, N.S., Saul, A.J., Tapsell, S.M., Watkinson, A.R., \& Wheater, H.S. (2008). An update of the Foresight Future Flooding 2004 qualitative risk analysis. Cabinet Office, London.

Falconer, R. (2009, November). Pluvial Flooding and Surface Water Management. European Water Management and Implementation of the Floods Directive. 5th EWA Brussels Conference, 6th November 2009, Brussels, Belgium.

Falconer, R., Cobby, D., Smyth, P., Astle, G., Dent, J., \& Golding, B. (2009). Pluvial flooding: New approaches in flood warning, mapping and risk management. Journal of Flood Risk Management, 2, 198 208. DOI: 10.1111/j.1753-318X.2009.01034.X

Falkenhagen, B. (2010, May). Flash flood and pluvial flooding from the point of view of the insurance industry. EUROPEAN COMMISSION - WFD COMMON IMPLEMENTATION STRATEGY, WG F Thematic Workshop on Implementation of the Floods Directive 2007/6o/EC, "FLASH FLOODS AND PLUVIAL FLOODING", $26^{\text {th }}-28^{\text {th }}$ May 2010, Cagliari, Italy

Faust, E. (2018). Parts of Germany under water. Available at: https://www.munichre.com/topics-online/ en/climate-change-and-natural-disasters/naturaldisasters/floods/floods-in-germany-2018.html

Fritsch, K. Assmann, A., \& Tyrna, B. (2016, October). Long-term experiences with pluvial flood risk management. 3rd European Conference on Flood Risk Management, E3S Web of Conferences. 7. 04017. 17 th - $21^{\text {st }}$ October, 2016, Lyon, France. DOI:10.1051/e3sconf/20160704017.

Gaume, E., Bain, V., Bernardara, P., Newinger, O., Barbuc, M., Bateman, A., Blaškovičová, L., Blöschl, G., Borga, M., Dumitrescu, A., Daliakopoulos, I., Garcia, J., Irimescu, A., Kohnová, S., Koutroulis, A., Marchi, L., Matreata, S., Medina, V., Preciso, E., \& Viglione, A. (2009). A Collation of Data on European Flash Floods. Journal of Hydrology, 367, 70-78. DOI:10.1016/j.jhydrol.2008.12.028

Gaume, E., Borga, M., Llassat, M.C., Maouche, S., Lang, M., \& Diakakis, M. (2016). Mediterranean extreme floods and flash floods.The Mediterranean Region under Climate Change. A Scientific Update, IRD Editions, 133-144, Coll.

Green, C., Dieperink, C., Ek, K., Hegger, D.L.T., Pettersson, M., Priest, S., \& Tapsell, S. (2013). Flood Risk Management in Europe: the flood problem and interventions (report no D1.1.1), STAR-FLOOD 
Consortium, Utrecht, the Netherlands. ISBN: $978-$ 94-91933-02-8

Guerreiro, S.B., Glenis, V., Dawson, R., \& Kilsby, C. (2017). Pluvial Flooding in European Cities-A Continental Approach to Urban Flood Modelling. Water, 9(4):296. DOI:10.3390/w9040296.

Houston, D., Werritty, A., Basset, D., Geddes, A., Hoolachan, A., \& Mcmillan, M. (2011). Pluvial (Rain Related) Flooding in Urban Areas: The Invisible Hazard. Project Report. Joseph Rowntree Foundation, Bristol.

Intergovernmental Panel on Climate Change - IPCC. (2014). Fifth Assessment Report - AR5 Climate Change 2014: Impacts, Adaptation, and Vulnerability. IPCC - Working Group Report

Jiang, Y., Zevenbergen, C., \& Ma, Y. (2018). Urban pluvial flooding and stormwater management: A contemporary review of China's challenges and "sponge cities" strategy. Environmental Science \& Policy, Volume 8o, 132-143. https://doi.org/10.1016/j. envsci.2017.11.016

Jongman, B. (2018). Effective adaptation to rising flood risk. Nature Communications, 9 (1). DOI: 10.1038/ s41467-018-04396-1

Jonkman, S.N., \& Vrijling, J.K. (2008). Loss of life due to floods. Journal of Flood Risk Management, 1(1):43 - 56. DOI:10.1111/j.1753-318X.2008.00006.x

Kaspersen, P. S., Høegh Ravn, N., Arnbjerg-Nielsen, K., Madsen, H., \& Drews, M. (2017). Comparison of the impacts of urban development and climate change on exposing European cities to pluvial flooding. Hydrology and Earth System Sciences, 21(8), 4131-4147. DOI: 10.5194/hess-21-4131-2017

Kaspersen, P.S., \& Kirsten, H. (2017). Integrated climate change risk assessment: A practical application for urban flooding during extreme precipitation. Climate Services, 6. DOI:10.1016/j.cliser.2017.06.012.

Kazmierczak, A., \& Cavan, G. (2011). Surface water flooding risk to urban communities: Analysis of vulnerability, hazard and exposure. Landscape and Urban Planning 103, 185- 197. DOI: 10.1016/j.landurbplan.2011.07.008

Kömüşcü, A.U., \& Çelik, S. (2012). Analysis of the Marmara flood in Turkey, 7-10 September 2009: an assessment from hydrometeorological perspective. Natural Hazards. DOI 10.1007/s11069-012-0521-x

Kundzewicz, Z.W., Pińskwar, I., \& Brakenridge, G.R. (2012). Large floods in Europe, 1985-2009, Hydrological Sciences Journal. DOI:10.1080/02626667.201 2.745082

Kundzewicz, Z.W. (2015). Climate change track in river floods in Europe. Proc. IAHS, 369, 189-194. DOI: 10.5194/piahs-369-189-2015

Land Use Consultants, CAG Consultants and SQW Limited (2003). Living with Climate Change in the
East of England. Stage 1 Report: Guidance on Spatial Issues. Technical Report prepared for Hertfordshire County Council on behalf of the East of England Regional Assembly and East of England Sustainable Development Roundtable

Li, C. (2012). Ecohydrology and good urban design for urban storm water-logging in Beijing, China. Ecohydrology \& Hydrobiology, 12(4):287-300. DOI:10.2478/v10104-012-0029-8.

Lugeri, N., Genovese, E., Lavalle, C., \& De Roo, A. (2006). Flood risk in Europe: analysis of exposure in 13 Countries. Institute for Environment and Sustainability and European Commission Joint Research Centre

Markošek, J. (2008). A case-study of an extreme rainfall event in NW Slovenia. The European Forecaster, Newsletter of the WGCEF, $\mathrm{N}^{\circ}{ }_{13}$, Météo-France.

Mees, H., Crabbé, A., Alexander, M., Kaufmann, M., Bruzzone, S., Lévy, L., \& Lewandowski J. (2016). Coproducing flood risk management through citizen involvement: insights from cross-country comparison in Europe. Ecology and Society 21(3):7. http:// dx.doi.org/10.5751/ES-08500-210307

Menne, B., \& Murray, V. (2013). Floods in the WHO European Region: Health effects and their prevention. World Health Organization, Regional Office for Europe, Copenhagen.

Miller, J.D., \& Hutchins, M. (2017). The impacts of urbanisation and climate change on urban flooding and urban water quality: A review of the evidence concerning the United Kingdom. Journal of Hydrology: Regional Studies 12, 345-362. https://doi. org/10.1016/j.ejrh.2017.06.006

Moreau, K., \& Roumagnac, A. (2010, September). Feedback on floods in Var, south of France, 15th June 2010: different societal impacts and responses linked to levels of prevention, organization and information. 12th Plinius Conference on Mediterranean Storms, 1st - 4th September 2010, Corfu Island, Greece.

Nicklin, H., Leicher, A.M., Dieperink, C., \& Van Leeuwen, K. (2019). Understanding the Costs of Inaction - An Assessment of Pluvial Flood Damages in Two European Cities. Water, 11(4):801. DOI: 10.339o/ w11040801.

Organisation for Economic Co-operation and Development - OECD. (2013). Water and Climate Change Adaptation: Policies to Navigate Uncharted Waters, OECD Studies on Water, OECD Publishing

Osnabrugge, B. van, Meissner, D., Macia-Sorribes, H., \& Louise Arna, L. (n.d.). Flood Early Warfning and Forecasting across Europe - An Insider's View by IMPREX Early Career Scientists. Available at: https://imprex.eu/flood-early-warning-and-forecasting-across-europe 
Pregnolato, M., Ford, A., Wilkinson, S.M., \& Dawson, R.J. (2017). The impact of flooding on road transport: A depth-disruption function. Transportation Research Part D: Transport and Environment, Volume 55, 67-81. https://doi.org/10.1016/j. trd.2017.06.020

Priest, S.J., Suykens, C., Van Rijswick, H.F.M.W., Schellenberger, T., Goytia, S.B., Kundzewicz, Z.W., Van Doorn-Hoekveld, W.J., Beyers, J.-C., \& Homewood, S. (2016). The European Union approach to flood risk management and improving societal resilience: lessons from the implementation of the Floods Directive in six European countries. Ecology and Society, 21(4):50. https://doi.org/10.5751/ES-o8913-210450

Rusjan, S., Kobold, M., \& Mikos, M. (2009). Characteristics of the extreme rainfall event and consequent flash floods in W Slovenia in September 2007. Nat. Hazards Earth Syst. Sci., 9, 947-956. https://doi. org/10.5194/nhess-9-947-2009

Santato, S., Bender, S., \& Schaller, M. (2013). The European Floods Directive and Opportunities offered by Land Use Planning. CSC Report 12, Climate Service Center, Germany

Schlünzen, K.H., \& Bohnenstengel, S.I. (2016). Socioeconomic Impacts-Urban Climate. In: Quante M., Colijn F. (eds) North Sea Region Climate Change Assessment. Regional Climate Studies. Springer, Cham. https://doi.org/10.1007/978-3-319-39745-0_15

Silk, J. (2019). Storm 'Axel' causes travel disruption, flooding in Germany, Austria. Available at: https:// www.dw.com/en/storm-axel-causes-travel-disruption-flooding-in-germany-austria/a-48820037

Sörensen, J., Persson, A., Sternudd, C., Aspegren, H., Nilsson, J., Nordström, J., Jonsson, K., Mottaghi, M., Becker, P., Pilesjö, P., Larsson, R., Berndtsson, R., \& Mobini, S. (2016). Re-Thinking Urban Flood Management-Time for a Regime Shift. Water, 8, 332. https://doi.org/10.3390/w8080332

Stuart-Menteth, A. (2007). U.K. Summer 2007 Floods. Risk Management Solutions.

Sušnik, J., Strehl, C., Postmes, L.A., VamvakeridouLyroudia, L.S., Maelzer, H.J., Savic, D.A., \& Kapelan, Z. (2014). Assessing Financial Loss due to Pluvial Flooding and the Efficacy of Risk-Reduction Measures in the Residential Property Sector. Water Resources Management, 29. DOI: 10.1007/ s11269-014-0833-6.

Swart, R.J., Fons, J., Geertsema, W., van Hove, L.W.A., \& Jacobs, C.M.J. (2012). Urban Vulnerability Indicators. A joint report of ETC-CCA and ETC-SIA. Technical Report, no. 01/2012, ETC CCA, Bologna

Szewrański, S., Chruściński, J., van Hoof, J., Kazak, J., Malgorzata, S., Tokarczyk-Dorociak, K., \& Żmuda, R. (2018a). A Location Intelligence System for the Assessment of Pluvial Flooding Risk and the Iden- tification of Storm Water Pollutant Sources from Roads in Suburbanised Areas. Water, 10(6):746. DOI: $10.3390 /$ w10060746.

Szewrański, S., Chruściński, J., van Hoof, J., Kazak, J., Malgorzata, S., Tokarczyk-Dorociak, K., \& Żmuda, R. (2018b). Pluvial Flood Risk Assessment Tool (PFRA) for Rainwater Management and Adaptation to Climate Change in Newly Urbanised Areas. Water, 10(4):386. DOI: 10.3390/w10040386.

The Technical and Environmental Administration, City of Copenhagen (2009). Copenhagen Climate Adaptation Plan, Copenhagen Carbon Neutral by 2025.

Wilson, D., \& Spiers, M. (2003, June). The Strategic Response to Glasgow East End Flooding, Paper No 4. Scottish WaPUG Meeting, 19th June 2003, Dunblane

World Meteorological Organisation. (2016). Overview of the Global FFG System. Third Hydrology Forum, $20^{\text {th }}-23^{\text {rd }}$ September 2016, Oslo, Norway.

Working Group F on Floods. (2010, May). Flash Floods and Pluvial Flooding Workshop. Report of Cagliari workshop, $26^{\text {th }}-28^{\text {th }}$ May 2010, Calgari, Italy. ISBN: 978-88-448-0511-1

Zhou, Q., Mikkelsen, P.S., Halsnæs, K., \& ArnbjergNielsen, K. (2012). Framework for economic pluvial flood risk assessment considering climate change effects and adaptation benefits. Journal of Hydrology, Volumes 414-415, 539-549. https:/doi. org/10.1016/j.jhydrol.2011.11.031

Internet 1: Amsterdam Rainproof https://www.rainproof.nl

Internet 2: Civil Engineering \& Environmental Hydraulics | HR Wallingford http://www.hrwallingford.com

Internet 3: Climate change and flood risk in European cities https://www.eea.europa.eu/highlights/climate-change-and-flood-risk

Internet 4: Facts About Floods In The UK - Flooding Statistics UK - Rainbow Int. https://rainbow-intfranchise.co.uk/flooding-statistics-uk/

Internet 5. Find out if you're at risk of flooding in England. https://www.gov.uk/check-flood-risk

Internet 6. Flash floods and Urban flooding. https:// www.climatechangepost.com

Internet 7. FloodCitiSense. https://jpi-urbaneurope. eu/project/floodcitisense/

Internet 8. FloodList - Floods and Flooding News from across the Globe. http://floodlist.com/

Internet 9. Four Cities Gain Rain. http://www.raingain.eu

Internet 10. Major flash floods hit urban areas of Catania, Sicily (2018). http://www.severe-weather.eu/ news/major-flash-floods-hit-urban-areas-of-catania-sicily/ 
Internet 11. Making Space for Water - Urban Flood Risk and Integrated Drainage (2008). https://webarchive.nationalarchives.gov.uk/20090731150607/ http://www.defra.gov.uk/environ/fcd/policy/strategy/ha2.htm

Internet 12. PLANAT National Platform for Natural Hazards Information platform on natural hazards in Switzerland. http://www.planat.ch
Internet 13. STAR-FLOOD.http://www.starflood.eu Internet 14. Urban-Prex. http://www.urban-prex.org Internet 15. Urban pluvial flooding and climate change: London (UK), Rafina (Greece) and Coimbra (Portugal). https://www.imperial.ac.uk/grantham/research/resources-and-pollution/water-security-and-flood-risk/urban-flooding/ 